https://doi.org/10.15407/ujpe63.12.1095

M.M. KRAS'KO, A.G. KOLOSIUK, V.V. VOITOVYCH, V.YU. POVARCHUK, I.S. ROGUTS'KYI

Institute of Physics, Nat. Acad. of Sci. of Ukraine

(46, Nauky Ave., Kyiv 03680,Ukraine; e-mail: krasko@iop.kiev.ua)

\title{
INFLUENCE OF DIVACANCY-OXYGEN DEFECTS ON RECOMBINATION PROPERTIES OF $n$-Si SUBJECTED TO IRRADIATION AND SUBSEQUENT ANNEALING
}

\begin{abstract}
The variation of recombination properties in $n$-Si grown by the Czochralski method, doped to the free electron concentration $n_{0} \sim 10^{14} \div 10^{16} \mathrm{~cm}^{-3}$, irradiated with ${ }^{60}$ Co $\gamma$-quanta or $1-\mathrm{MeV}$ electrons, and isochronously annealed for 20 min in the temperature interval $180-380^{\circ} \mathrm{C}$, in which divacancy-oxygen $\left(V_{2} \mathrm{O}\right)$ complexes are formed and annealed, has been studied in detail. The nonequilibrium charge carrier lifetime $\tau$ is found to significantly decrease after the annealing in a temperature interval from 180 to $280^{\circ} \mathrm{C}$, with the effect being stronger for low-resistive $n$-Si. It is shown that a change in $\tau$ after the annealing at $180-380^{\circ} \mathrm{C}$ is caused by divacancy defects, most probably $\mathrm{V}_{2} \mathrm{O}$. By analyzing the experimental data with the help of the ShockleyRead-Hall statistics, it is found that the formation of $V_{2} O$ defects is characterized by an activation energy of $1.25 \pm 0.05 \mathrm{eV}$ and a frequency factor of $(1 \pm 0.5) \times 10^{9} \mathrm{~s}^{-1}$, and their annealing by an activation energy of $1.54 \pm 0.09 \mathrm{eV}$ and a frequency factor of $(2.1 \pm 1.4) \times 10^{10} \mathrm{~s}^{-1}$. The values of the hole capture cross-sections by singly and doubly charged acceptor states of $\mathrm{V}_{2} \mathrm{O}$ are obtained as: $(5 \pm 2) \times 10^{-13}$ and $(8 \pm 4) \times 10^{-12} \mathrm{~cm}^{2}$, respectively.
\end{abstract}

Ke ywords: gamma irradiation, divacancy-oxygen defect, charge carrier lifetime, silicon.

\section{Introduction}

Among the integral parameters of silicon, the lifetime of charge carriers, $\tau$, is the most sensitive to the radiation action. As a rule, $\tau$ can vary by orders of magnitude in silicon irradiated with $\gamma$-quanta or afew-MeV electrons, whereas the carrier concentration or mobility practically does not change at that. The degradation of $\tau$ in irradiated silicon is caused by the formation of radiation-induced defects, which are effective recombination centers [1-4]. That is why the application of radiation-induced defects as the centers of charge carrier recombination forms the basis of radiation-technological methods for the fabrication of power silicon-based devices. In general, the parameter $\tau$ in silicon is sensitive to the presence of various defects, which makes it a powerful tool to study the defect properties of this material and to control its quality [5].

(C) M.M. KRAS'KO, A.G. KOLOSIUK, V.V. VOITOVYCH, V.YU. POVARCHUK, I.S. ROGUTS'KYI, 2018

ISSN 2071-0194. Ukr. J. Phys. 2018. Vol. 63, No. 12
In this work, our attention is focused on the influence of divacancy-oxygen $\left(\mathrm{V}_{2} \mathrm{O}\right)$ defects on the recombination properties of $n$-Si. The $\mathrm{V}_{2} \mathrm{O}$ complex was identified in EPR studies of electron-irradiated $\mathrm{Cz} \mathrm{Si}$ as long ago as in 1976. However, the positions of its electron levels in the forbidden band were discovered recently, when $\mathrm{V}_{2} \mathrm{O}$ was started to be considered as the main candidate responsible for the degradation of silicon detectors of ionizing particles $[7,8]$. Now, it was found $[9-16]$ that the annealing of irradiated $\mathrm{Cz}$ or diffusion oxygenated float-zone (DOFZ) silicon in the temperature interval $200-300^{\circ} \mathrm{C}$ leads to the interaction between a mobile divacancy $\mathrm{V}_{2}$ and an interstitial oxygen atom $\mathrm{O}_{i}$. As a result of this interaction, a $\mathrm{V}_{2} \mathrm{O}$ defect is formed, which is annealed at temperatures of about $300-350^{\circ} \mathrm{C}$. The transformation $\mathrm{V}_{2} \rightarrow \mathrm{V}_{2} \mathrm{O}$ occurs with a proportionality of $1: 1$. In work [17], the electron level with an energy of $\sim E_{c}-0.55 \mathrm{eV}$ was attributed to $\mathrm{V}_{2} \mathrm{O}(-/ 0)$. However, a detailed study of the $\mathrm{V}_{2}$ annealing kinetics in $\mathrm{Cz}$ and DOFZ silicon revealed another spectrum of $\mathrm{V}_{2} \mathrm{O}$ 
levels. In particular, the electron levels of $\mathrm{V}_{2}$ and $\mathrm{V}_{2} \mathrm{O}$ turned out very similar. Two new levels in $n$-Si located at $\sim E_{c}-0.23 \mathrm{eV}$ and $\sim E_{c}-0.47 \mathrm{eV}$ were associated with doubly and singly charged acceptor states of $\mathrm{V}_{2} \mathrm{O}[9-12]$. A new level at $\sim E_{v}+0.23 \mathrm{eV}$ in $p$-Si was identified as a donor state of $\mathrm{V}_{2} \mathrm{O}(+/ 0)$ [13-16]. At the same time, the level at $\sim E_{v}+0.08 \mathrm{eV}$ is considered as $\mathrm{V}_{2} \mathrm{O}(2+/+)[14,16]$.

Most of the above-mentioned researches were aimed at studying the electron properties of $\mathrm{V}_{2} \mathrm{O}$. The influence of these defects on the variation of integral parameters (in particular, the charge carrier lifetime) of $\mathrm{Cz}$ Si remains almost unstudied. Nevertheless, the data in works $[18,19]$ testify to a relation between the changes of $\tau$ and the formation of $\mathrm{V}_{2} \mathrm{O}$ defects in $\mathrm{Cz} n$-Si crystals ${ }^{60} \mathrm{Co} \gamma$-irradiated and annealed in a temperature interval of about $200-400^{\circ} \mathrm{C}$, as well as in the case of electron irradiation in the same temperature interval. Being characterized by a high thermal stability and having deep levels in the forbidden $\mathrm{Si}$ region, $\mathrm{V}_{2} \mathrm{O}$ defects can serve as effective recombination centers in silicon and silicon-based devices.

In this paper, we studied the degradation of the lifetime of nonequilibrium charge carriers in ${ }^{60} \mathrm{Co}$ $\gamma$-irradiated and $1-\mathrm{MeV}$-electron-irradiated $\mathrm{Cz} n$-Si $\left(n_{0} \sim 10^{14} \div 10^{16} \mathrm{~cm}^{-3}\right)$ after its isochronous annealing in a temperature interval of $20-380^{\circ} \mathrm{C}$. In this context, an interval of about $180-380^{\circ} \mathrm{C}$ was analyzed in detail in order to determine the role of $\mathrm{V}_{2} \mathrm{O}$ defects in the modification of $\mathrm{Cz} n$-Si recombination properties.

\section{Experimental Part}

\subsection{Experimental specimens}

Two groups of $n$-type silicon specimens were used.

(i) $n$-Si : P. The phosphorus (P) impurity created the conductivity of the $n$-type in $\mathrm{Si}$. Some specimens from this group had a high concentration of carbon impurities (n-Si : P,C).

(ii) $n$-Si:TD. Oxygen thermodonors (TDs) were responsible for the donor properties of $\mathrm{Si}$ specimens in this group. The $n$-Si : TD specimens were obtained by thermally treating the high-resistive $n$-Si $(P \sim$ $\left.1 \times 10^{13} \mathrm{~cm}^{-3}\right)$ at $450^{\circ} \mathrm{C}$. The condition $[\mathrm{TD}] /[\mathrm{P}]>50$ was obeyed at that. Thermodonors, unlike phosphorus atoms, are insensitive to irradiation. They do not create complexes with radiation-induced vacancies (like VP defects) and do not lose their donor activity under irradiation [20].
The specimen parameters (the initial concentrations of free electrons, $n_{0}$, oxygen, $\mathrm{O}_{i}$, and carbon, $\mathrm{C}_{s}$, as well as the lifetime $\tau_{0}$ of nonequilibrium charge carriers before irradiation, are quoted in Table 1 for both groups.

\subsection{Specimen irradiation and annealing}

The experimental specimens were irradiated at room temperature with ${ }^{60} \mathrm{Co} \gamma$-quanta to a dose of about $7 \times 10^{14} \mathrm{~cm}^{-2}$ [the radiation intensity $J_{\gamma} \approx 2 \times$ $10^{11}$ quantum $\left./\left(\mathrm{cm}^{2} \mathrm{~s}\right)\right]$ and $1-\mathrm{MeV}$ electrons with to a dose of $1 \times 10^{13} \mathrm{~cm}^{-2}\left[J_{e} \approx 3 \times 10^{11}\right.$ electrons $\left./\left(\mathrm{cm}^{2} \mathrm{~s}\right)\right]$. The irradiated specimens were isochronously (for $20 \mathrm{~min}$ ) annealed in the air atmosphere in a temperature interval of $20-380^{\circ} \mathrm{C}$.

\subsection{Measurement and analysis procedures}

The lifetime of charge carriers in the specimens was determined from the nonequilibrium photoconductivity relaxation under low-excitation conditions $\left(\Delta n / n_{0} \approx 1 \%\right)$. The determination error for $\tau$ did not exceed $\pm 10 \%$. The influence of the irradiation and subsequent annealing was estimated, by using the known relation

$\tau^{-1}=\tau_{0}^{-1}+k_{\tau} \Phi$

where $\tau_{0}$ is the initial lifetime of nonequilibrium charge carriers, $\tau$ the lifetime of nonequilibrium charge carriers after the irradiation to the dose $\Phi$ and the subsequent annealing, and $k_{\tau}$ the $\tau$-degradation constant.

The experimental results were analyzed with the help of the Shockley-Read-Hall statistics. In our case ( $n$-Si, a low defect concentration, $\Delta n \ll n_{0}$, and

Table 1. Specimen parameters

\begin{tabular}{|l|c|c|c|c|}
\hline Specimen & $\begin{array}{c}n_{0}, 10^{15} \\
\mathrm{~cm}^{-3}\end{array}$ & $\begin{array}{c}\tau_{0}, \\
\mu \mathrm{s}\end{array}$ & $\begin{array}{c}{\left[\mathrm{C}_{s}\right],} \\
10^{16} \mathrm{~cm}^{-3}\end{array}$ & $\begin{array}{c}{\left[\mathrm{O}_{i}\right],} \\
10^{17} \mathrm{~cm}^{-3}\end{array}$ \\
\hline \multirow{3}{*}{$n$-Si : P } & $\sim 0.1$ & $110-130$ & $<5$ & $6-9$ \\
& $\sim 1$ & $80-90$ & $<5$ & \\
& $\sim 2$ & $120-130$ & $<5$ & \\
& $\sim 5.5$ & $90-100$ & $<5$ & \\
& $\sim 1$ & $50-60$ & $\sim 40$ & \\
$n$-Si : TD & $\sim 0.5$ & $50-55$ & $<5$ & $8-9$ \\
& $\sim 1$ & $55-60$ & $<5$ & \\
& $\sim 8.5$ & $75-80$ & $<5$ & \\
\hline
\end{tabular}

ISSN 2071-0194. Ukr. J. Phys. 2018. Vol. 63, No. 12 
the charge carrier recombination occurs through levels in the upper half of the band gap), the lifetime of nonequilibrium charge carriers is governed by the lifetime of holes (minority charge carriers in $n$-Si), and the following expression is valid for every recombination center:

$\tau_{i}=\left(\sigma_{p, i} v_{p}\left[N_{i}\right]\right)^{-1}\left[1+\frac{N_{c} \exp \left(-E_{i} / k_{\mathrm{B}} T\right)}{n_{0}}\right]$,

where $\sigma_{p, i}$ is the hole capture cross-section by the $i$ th recombination center, $v_{p}$ the heat velocity of holes, $N_{i}$ the concentration of the $i$-th center with the level $E_{i}, N_{c}$ the effective density of states in the conduction band, $k_{\mathrm{B}}$ the Boltzmann constant, and $T$ the absolute temperature. The total change of $\tau$ is determined as the sum of the partial contributions $\tau_{i}$,

$\tau^{-1}-\tau_{0}^{-1}=\sum_{i} \tau_{i}^{-1}$

Then, from Eq. (1) and taking Eqs. (2) and (3) into account, the following expression is obtained for the degradation constant of the charge carrier lifetime:

$k_{\tau}=\sum_{i} \sigma_{p, i} v_{p} \eta_{i}\left[1+\frac{N_{c} \exp \left(-E_{i} / k_{\mathrm{B}} T\right)}{n_{0}}\right]^{-1}$,

where $\eta_{i}=\left[N_{i}\right] / \Phi$ is the efficiency of the $i$-th recombination center formation.

\section{Results and Their Discussion}

In the general case, the change of $\tau$ in an irradiated and subsequently annealed silicon specimen means the annealing or the additional formation of the main recombination center or the formation of a new one, which is more recombinationally active than those formed after the irradiation. Therefore, the change of $\tau$ was studied firstly after the irradiation and then after the irradiation and subsequent annealing.

\subsection{The change of $\tau$ in ${ }^{60}$ Co $\gamma$-irradiated $C z n-S i$}

Figure 1 demonstrates the dose dependences of $\Delta \tau^{-1}$ for $(a) n$-Si : $\mathrm{P}$ and $(b) n$-Si : TD specimens with various free electron concentrations $n_{0}$ irradiated with ${ }^{60} \mathrm{Co} \gamma$-quanta. One can see that $\Delta \tau^{-1}$ linearly depends on $\Phi$ for all specimens in both groups. This circumstance makes it possible to determine the experimental values of $k_{\tau}^{\text {irr }}$ with the help of expression
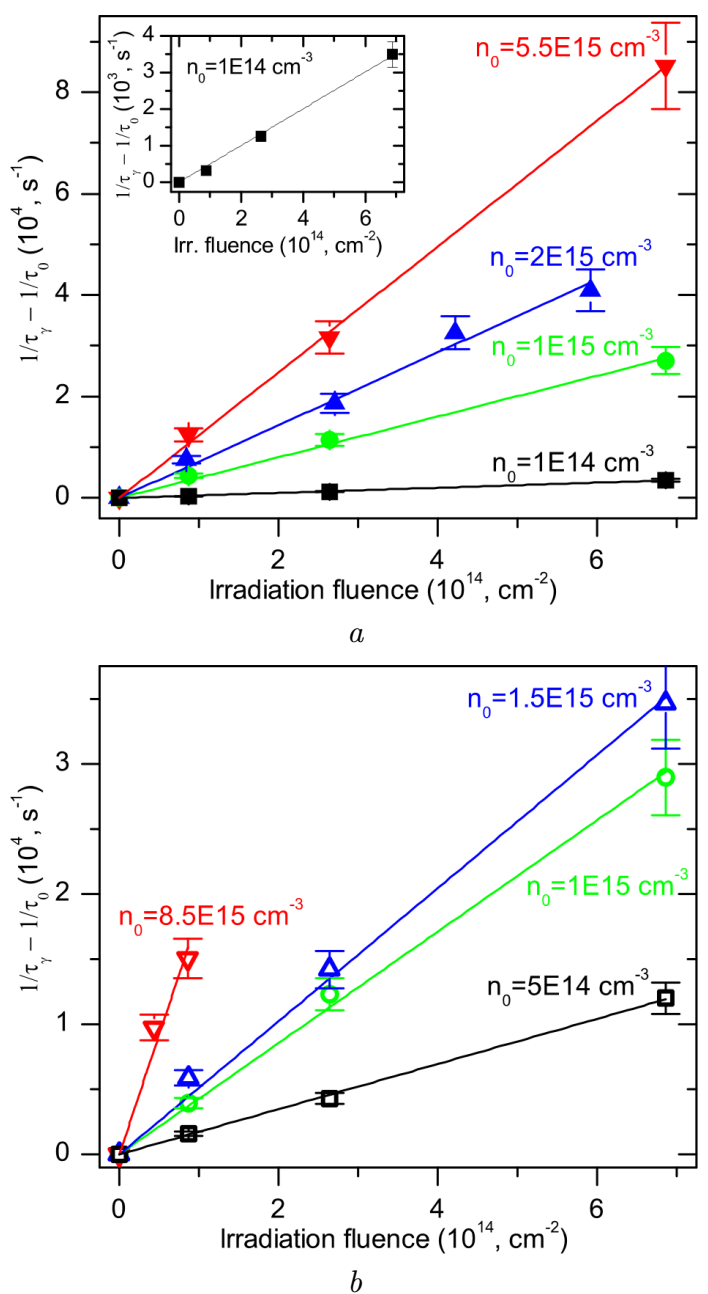

Fig. 1. Dependences of $\Delta \tau^{-1}$ on the irradiation fluence with ${ }^{60} \mathrm{Co} \gamma$-quanta for $n$-Si:P $(a)$ and n-Si:TD $(b)$ specimens with various free electron concentrations $n_{0}$ (points correspond to experimental data, and solid curves to their linear approximations

(1). At the same time, the dependence $k_{\tau}^{\text {irr }}\left(n_{0}\right)$ for the $\gamma$-irradiated $n$-Si:P and $n$-Si:TD specimens is increasing (see Fig. 2), and the experimental points for both $n$-Si groups lie on the same curve.

It is known that the vacancy-oxygen impurity atom complexes (VO or A-centers, an acceptor level of $\left.E_{c}-0.17 \mathrm{eV}\right)$ are the main recombination centers in ${ }^{60} \mathrm{Co} \gamma$-irradiated $\mathrm{Cz} n$-Si:P $[4,21-23]$ and $n$ $\mathrm{Si}$ : TD [22] at room temperature and a low excitation (injection). This fact is also confirmed by our calculations. The solid curve in Fig. 2 describes the contribution of VO-centers to the change of $\tau$ af- 


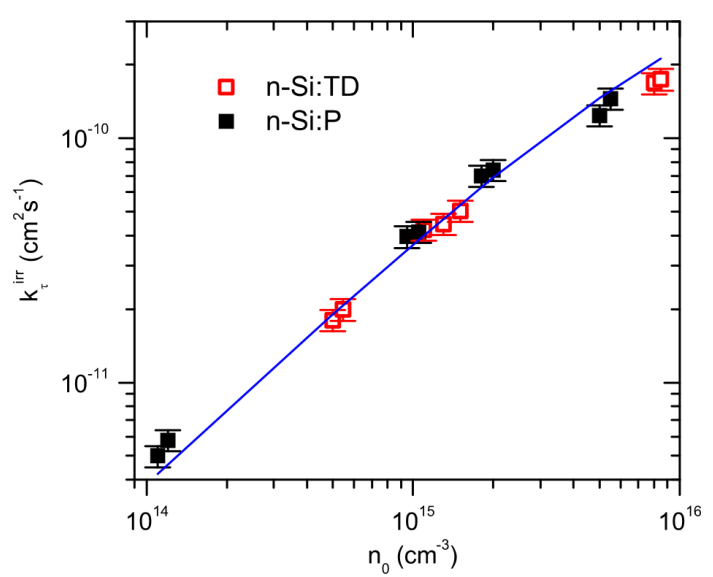

Fig. 2. Dependence of $k_{\tau}^{\text {irr }}$ on the free electron concentration $n_{0}$ for ${ }^{60}$ Co $\gamma$-irradiated n-Si : P and n-Si : TD specimens. Symbols correspond to experimental data, the solid line is the calculated contribution of VO defects

ter the $\gamma$-irradiation calculated according to expression (4). When approximating the experimental dependence $k_{\tau}^{\text {irr }}\left(n_{0}\right)$, the quantity $\sigma_{p}$,vo was the only fitting parameter, and the experimental value $\eta_{\mathrm{VO}} \approx$ $\approx 4 \times 10^{-4} \mathrm{~cm}^{-1}$ for ${ }^{60} \mathrm{Co} \gamma$-irradiated $\mathrm{Cz} n$-Si specimens in both groups was taken from works [22, 23]. The calculation and experimental results are in good agreement, if $\sigma_{p, \mathrm{VO}}=(2.0 \pm 0.4) \times 10^{-13} \mathrm{~cm}^{2}$, similarly to the results obtained in our previous [22] and other $[3,23]$ researches. The growth of the dependence $k_{\tau}^{\text {irr }}\left(n_{0}\right)$ in Fig. 2 occurs due to an increase in the occupation degree of the electron level of VO-centers in low-resistive specimens.

\subsection{Change of $\tau$ in ${ }^{60}$ Co $\gamma$-irradiated Cz $n-S i$ at the isochronous annealing in a temperature interval of $20-380^{\circ} \mathrm{C}$}

\subsubsection{Isochronous annealing}

Figure 3 demonstrates the typical experimental dependences of $k_{\tau}$ on the isochronous (20 min) annealing temperature $T_{\text {ann }}$ in an interval of $20-380^{\circ} \mathrm{C}$ for $\gamma$-irradiated $\mathrm{Cz} n$-Si:P $(a)$ and $n$-Si:TD (b) specimens with various free electron concentrations $n_{0}$. The main characteristic features are as follows.

- All $k_{\tau}\left(T_{\text {ann }}\right)$ dependences are qualitatively similar for $\mathrm{Cz} n$-Si specimens in both groups and with different $n_{0}$-values. Annealing to about $180^{\circ} \mathrm{C}$ practically does not affect $k_{\tau}$. Substantial changes occur in an interval of $180-380^{\circ} \mathrm{C}$. Namely, $k_{\tau}$ drastically increases to $T_{\text {ann }} \approx 240 \div 280^{\circ} \mathrm{C}$ and, at the subsequent anneal-
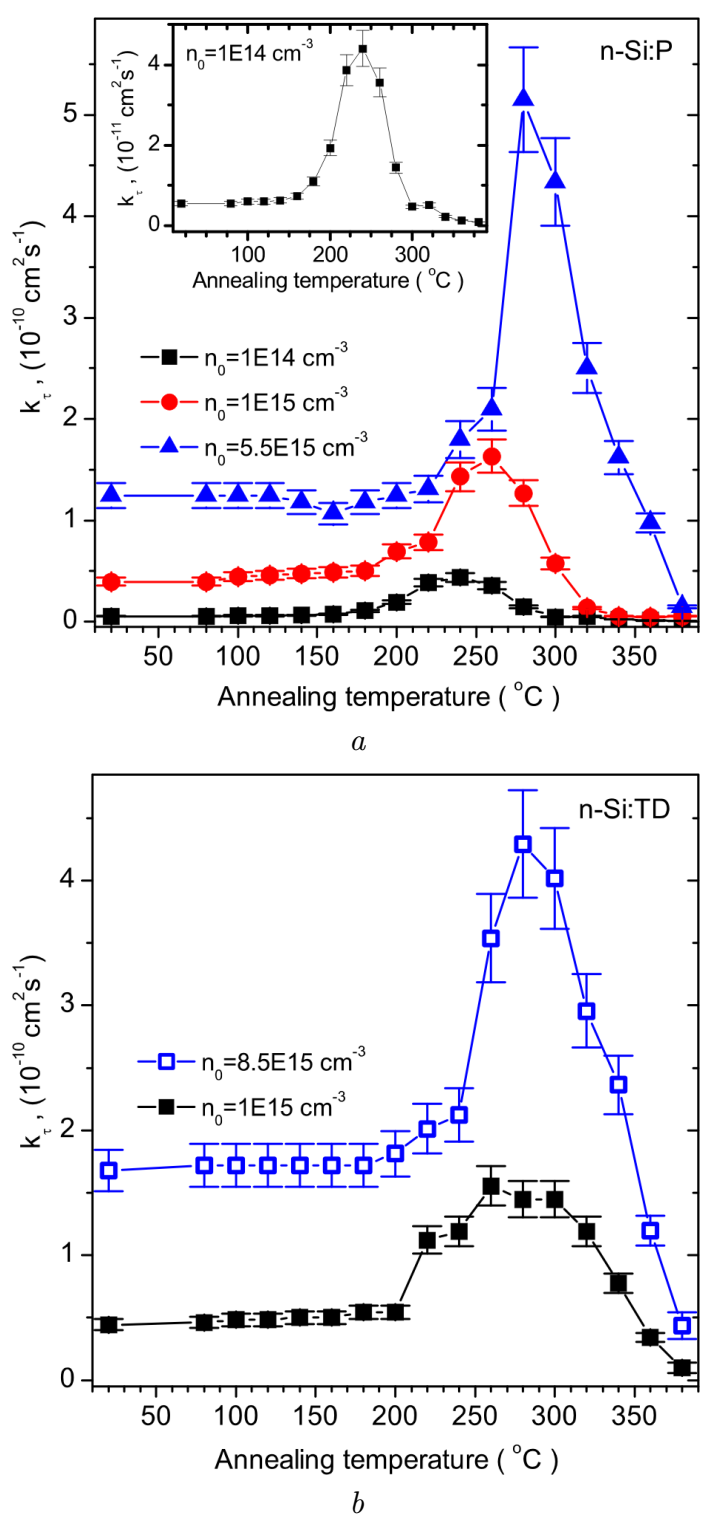

Fig. 3. Dependences of $k_{\tau}$ on the isochronous (20 min) annealing temperature for ${ }^{60} \mathrm{Co} \gamma$-irradiated $\mathrm{Cz}$ n-Si:P $(a)$ and n-Si:TD (b) specimens with various free electron concentrations $n_{0}$ 's

ing, decreases to a value corresponding to $80-90 \%$ of $\tau_{0}$ at $T_{\text {ann }} \approx 360 \div 380^{\circ} \mathrm{C}$. Note also that a peak-like change of $k_{\tau}$ in the interval from 180 to $380^{\circ} \mathrm{C}$ clearly correlates with the formation and annealing of $\mathrm{V}_{2} \mathrm{O}$ defects in $\mathrm{Cz} n$-Si (see Fig. 5 in work [11]).

- The height of the peak $\Delta k_{\tau}^{\text {peak }}=k_{\tau}^{\text {peak }}-k_{\tau}^{\text {irr }}$ in the dependences $k_{\tau}\left(T_{\text {ann }}\right)$ is determined by the parameter $n_{0}$ (see Fig. 4). From Fig. 4 (curve 1),

ISSN 2071-0194. Ukr. J. Phys. 2018. Vol. 63, No. 12 
one can see that the growth of $n_{0}$ from $1 \times 10^{14}$ to $8.5 \times 10^{15} \mathrm{~cm}^{-3}$ induces an 8 -fold increase of the peak height $\Delta k_{\tau}^{\text {peak }}$, which is stronger in low-resistive $n$-Si $\left(n_{0}>5 \times 10^{14} \mathrm{~cm}^{-3}\right)$. However, by comparing the absolute values of $\Delta k_{\tau}^{\text {peak }}$ in curve 1 in Fig. 4 and $k_{\tau}^{\text {irr }}$ in Fig. 2 in the examined $n_{0}$-interval, it is evident that the annealing effect on the $\tau$-degradation in $\gamma$-irradiated $\mathrm{Cz} n$-Si specimens is much more pronounced in high-resistive specimens. For example, the ratio $\Delta k_{\tau}^{\text {peak }} / k_{\tau}^{\text {irr }} \approx 10$ for specimens with $n_{0}=1 \times 10^{14} \mathrm{~cm}^{-3}$ and about 3 for specimens with $n_{0}=5.5 \times 10^{15} \mathrm{~cm}^{-3}$.

- There is also a tendency that the peak shifts toward higher temperatures with the increase of $n_{0}$. In our case, this shift amounted to about $40^{\circ} \mathrm{C}$ (see Fig. 3,a).

\subsubsection{The origin of $\tau$} variation at isochronous annealing

The degradation of $\tau$ in the $T_{\text {ann-interval from } 180}$ to $240-280^{\circ} \mathrm{C}$ (Fig. 3) testifies to the formation of either VO complexes (the major recombination centers after ${ }^{60} \mathrm{Co} \gamma$-irradiation) or more efficient recombination centers. The temperature interval 180 $300^{\circ} \mathrm{C}$ corresponds to the annealing interval of $\mathrm{V}_{2}$ in $\mathrm{Cz}$ and DOFZ Si [9-16]. The efficiency of the VO center formation in ${ }^{60} \mathrm{Co} \gamma$-irradiated $\mathrm{Cz} n$-Si specimens at room temperature is approximately two orders of magnitude higher than that of the $\mathrm{V}_{2}$ formation [1,23]. Therefore, an additional formation of VO centers due to a possible dissociation of $\mathrm{V}_{2}\left(\mathrm{~V}_{2} \rightarrow\right.$ $\rightarrow \mathrm{V}+\mathrm{V} \rightarrow \mathrm{VO}$ ) cannot change $\tau$ by an order of magnitude (or even by several times). Accordingly, the annealing of $\mathrm{V}_{2}$ has to result in the formation of another defect of the divacancy nature, which is confirmed by the results of the following experiment.

A $\mathrm{Cz} n$-Si specimen about $2.5 \mathrm{~mm}$ in thickness was irradiated with $1 \mathrm{MeV}$ electrons from one of its largest faces at room temperature, whereas the lifetime was measured at both faces. A comparison of DLTS spectra obtained for them (see Fig. 1 in our work [24]) demonstrates that the peaks associated with singly $\left(E 3, E_{c}-0.42 \mathrm{eV}\right)$ and doubly charged $\left(E 2, E_{c}-0.23 \mathrm{eV}\right)$ acceptor $\mathrm{V}_{2}$ states were registered only on the irradiated side of the specimen, whereas the peak of $\mathrm{VO}$ centers $\left(E 1, E_{c}-0.17 \mathrm{eV}\right)$ on the both sides, although the efficiency of the VO center formation on the shadow side was lower by almost an

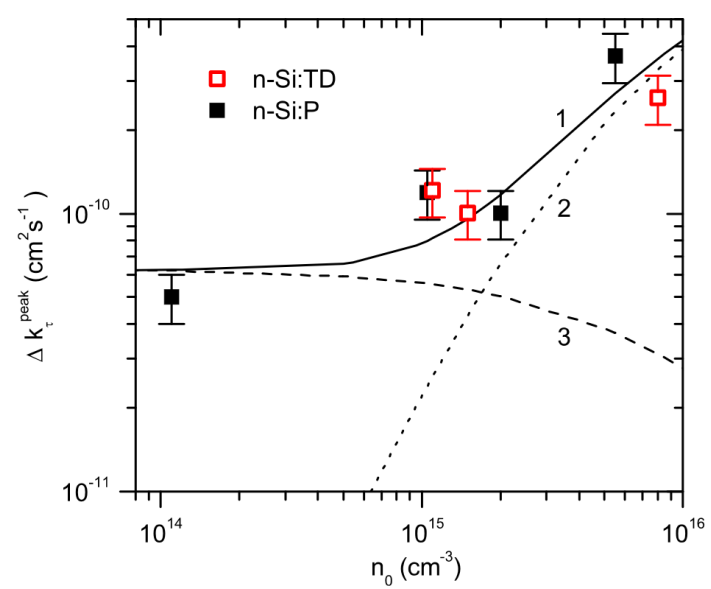

Fig. 4. Dependences of the peak height $\Delta k_{\tau}^{\text {peak }}=k_{\tau}^{\text {peak }}-k_{\tau}^{\text {irr }}$ in the dependences $k_{\tau}\left(T_{\text {ann }}\right.$ ) (see Fig. 3) on $n_{0}$. Symbols correspond to experimental data; curves to the calculated contribution of $\mathrm{V}_{2} \mathrm{O}$ defects: total (3) 3 ), $\mathrm{V}_{2} \mathrm{O}(2-/-)(2), \mathrm{V}_{2} \mathrm{O}(-/ 0)$

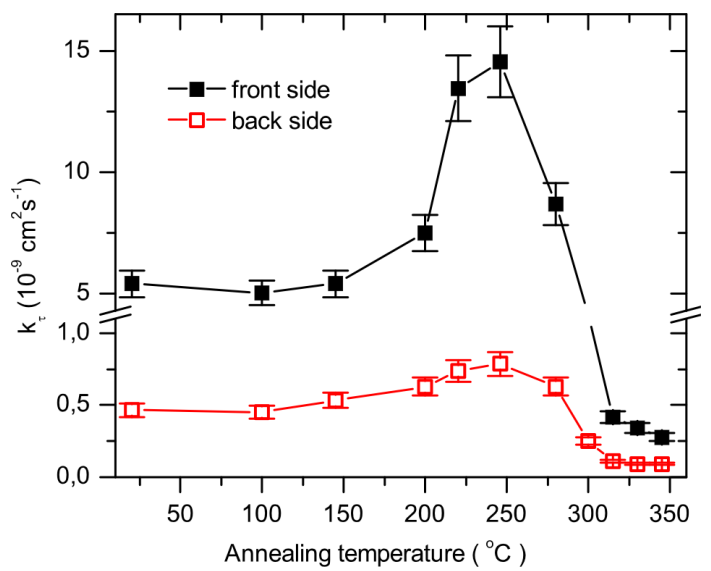

Fig. 5. Dependences of $k_{\tau}$ on the isochronous (20 min) annealing temperature for the front and back sides of the $\mathrm{Cz} n$ Si : $\left[P \approx 1 \times 10^{15} \mathrm{~cm}^{-3}\right]$ specimen about $2.5 \mathrm{~mm}$ in thickness $1-\mathrm{MeV}$-electron-irradiated to the dose $\Phi=1 \times 10^{13} \mathrm{~cm}^{-2}$

order of magnitude. This fact means that the energy of electrons at the shadow side of the specimen was lower or close to the threshold energy of the $V_{2}$ formation. In this case, if the changes of $\tau$ in the interval from 180 to $380^{\circ} \mathrm{C}$ (Fig. 3) were induced by the divacancy defect, then they should not be observed at the shadow side of the specimen.

Figure 5 exhibits the experimental dependences $k_{\tau}\left(T_{\text {ann }}\right)$ in the interval of $20-350^{\circ} \mathrm{C}$ measured for the specimen sides irradiated with $1-\mathrm{MeV}$ electrons (the front side) and not (the back side). One can see 


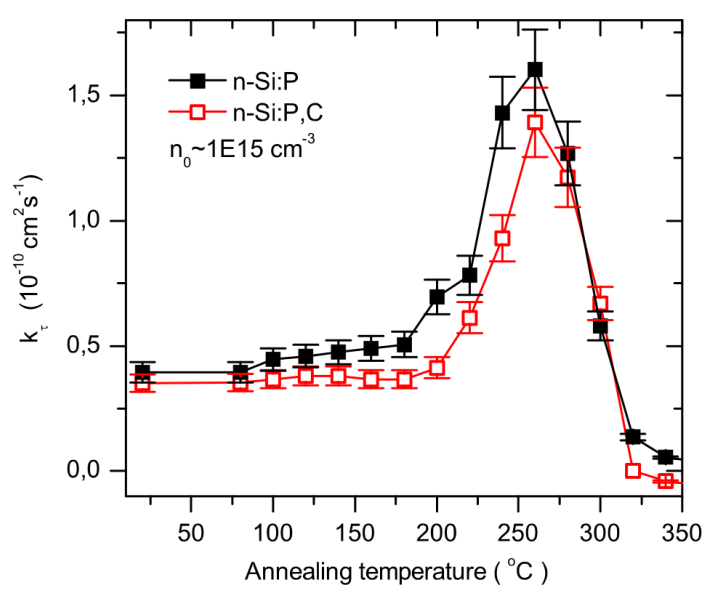

Fig. 6. Dependences of $k_{\tau}$ on the isochronous (20 min) annealing temperature for ${ }^{60} \mathrm{Co} \gamma$-irradiated $\left(\Phi=7 \times 10^{14} \mathrm{~cm}^{-2}\right)$ specimens with various carbon concentrations $\left[\mathrm{C}_{s}\right]$ : $4 \times 10^{16} \mathrm{~cm}^{-3}$ for $n$-Si : P and $4 \times 10^{17} \mathrm{~cm}$ for $n$-Si : P, C

that the ratio between the $k_{\tau}^{\text {irr }}$ values measured at those sides $\left(T=20^{\circ} \mathrm{C}\right.$ in Fig. 5$)$ is about an order of magnitude, being the same as the ratio for the VO formation efficiency in the DLTS spectra (see Fig. 1 in work [24]). It is important that, for the shadow side of the specimen, where $\mathrm{V}_{2}$ were not observed in the DLTS spectra, the relative height of the $\left(k_{\tau}^{\text {peak }}-k_{\tau}^{\text {irr }}\right) / k_{\tau}^{\text {irr }}$ peak is significantly smaller than for the irradiated one (about 0.5 and 2, respectively). The presence of a small peak in the dependence $k_{\tau}\left(T_{\text {ann }}\right)$ for the shadow side can be explained by the fact that DLTS measurements were carried out in the near-surface layer about $10 \mu \mathrm{m}$ in thickness, whereas the recombination region size is about $0.15-0.50 \mathrm{~mm}$, and the electron energy in this region is already higher than the threshold energy of the $\mathrm{V}_{2}$ formation. Thus, the formation of new divacancy defects stimulates the degradation of $\tau$ at the specimen side irradiated with $1 \mathrm{MeV}$ electrons (Fig. 5) and, accordingly, in $\gamma$-irradiated specimens (Fig. 3) at their isochronous annealing in a temperature interval of $180-300^{\circ} \mathrm{C}$.

It is most probably that those defects are $\mathrm{V}_{2} \mathrm{O}$ complexes. First, the DLTS study of the kinetics of $\mathrm{V}_{2}$ annealing and $\mathrm{V}_{2} \mathrm{O}$ formation in $\mathrm{Cz}$ and DOFZ $n$ $\mathrm{Si}$ shows that the transformation of $\mathrm{V}_{2}$ into $\mathrm{V}_{2} \mathrm{O}$ occurs with a proportionality of $1: 1$ [9-12]. Second, the variation of $k_{\tau}$ in the temperature interval from 180 to $380^{\circ} \mathrm{C}$ (Figs. 3 and 5) clearly correlates with the formation and annealing of $\mathrm{V}_{2} \mathrm{O}$ defects in $\mathrm{Cz} n-\mathrm{Si}$ (see Fig. 5 in work [11]). In work [21] on the basis of the temperature dependences of $\tau$ in $\gamma$-irradiated and then annealed high-resistive $\mathrm{Cz} n$-Si specimens $\left(n_{0}=7 \times 10^{13} \mathrm{~cm}^{-3}\right)$, it was shown that the $\tau$ degradation is driven by an acceptor with a level of $E_{c}-0.45 \mathrm{eV}$ (supposedly, this is $\mathrm{C}_{i} \mathrm{O}_{i}-\mathrm{V}_{2}$ ). However, the recent DLTS researches do not support this hypothesis. Moreover, the formation of $\mathrm{C}_{i} \mathrm{O}_{i}-\mathrm{V}_{2}$ complexes in ${ }^{60} \mathrm{Co} \gamma$-irradiated $\mathrm{Cz} n$-Si to low doses is hardly probable, because the concentration of $\mathrm{C}_{i} \mathrm{O}_{i}$ complexes, as well as the concentrations of all other radiation-induced defects, is much lower than the concentration of $\mathrm{O}_{i}$ (in our case, almost by six orders of magnitude). Note also that the level of this defect is practically the same as the position of $\mathrm{V}_{2} \mathrm{O}(-/ 0)$. Figure 6 demonstrates the experimental dependences $k_{\tau}\left(T_{\text {ann }}\right)$ for $\gamma$-irradiated $\mathrm{Cz} n$-Si specimens with various $\mathrm{C}_{s}$ concentrations. It is evident that the growth of $\left[\mathrm{C}_{s}\right]$ from about $4 \times 10^{16}$ to $4 \times 10^{17} \mathrm{~cm}^{-3}$ does not affect the behavior of $\tau$ annealing.

\subsubsection{Analysis of $\tau$}

variation at isochronous annealing

According to the results of our researches, the variation of $\tau$ in the dependences $k_{\tau}\left(T_{\text {ann }}\right)$ within a temperature interval of $180-380^{\circ} \mathrm{C}$ (see Fig. 3) takes place due to the formation (from 180 to $240-280^{\circ} \mathrm{C}$ ) and annealing (from $240-280$ to $380^{\circ} \mathrm{C}$ ) of $\mathrm{V}_{2} \mathrm{O}$ complexes. Then, in the examined case, the total changes of $\tau$ after the irradiation and subsequent annealing can be presented, according to expression (3), as the sum of the $\mathrm{VO}$ and $\mathrm{V}_{2} \mathrm{O}$ contributions:

$\tau^{-1}-\tau_{0}^{-1}=\tau_{\mathrm{VO}}^{-1}+\tau_{\mathrm{V}_{2} \mathrm{O}(-/ 0)}^{-1}+\tau_{\mathrm{V}_{2} \mathrm{O}(2-/-)}^{-1}$,

where the contribution of each defect is determined by formula (2). The system of kinetic equations that describes the processes of $\mathrm{V}_{2} \mathrm{O}$ formation $\left(\mathrm{V}_{2}+\mathrm{O} \rightarrow\right.$ $\left.\rightarrow \mathrm{V}_{2} \mathrm{O}\right)$ and annealing can be written in the form

$$
\left\{\begin{array}{l}
\frac{d\left[\mathrm{~V}_{2}\right]}{d t}=-c_{\mathrm{V}_{2} \mathrm{O}}\left[\mathrm{V}_{2}\right] \\
\frac{d\left[\mathrm{~V}_{2} \mathrm{O}\right]}{d t}=c_{\mathrm{V}_{2} \mathrm{O}}\left[\mathrm{V}_{2}\right]-c_{\mathrm{V}_{2} \mathrm{O}}^{\mathrm{ann}}\left[\mathrm{V}_{2} \mathrm{O}\right]
\end{array}\right.
$$

where $\left.c_{\mathrm{V}_{2} \mathrm{O}}=c_{0} \exp \left[-E_{a} /\left(k_{\mathrm{B}} T\right)\right]\right)$ and $c_{\mathrm{V}_{2} \mathrm{O}}^{\mathrm{ann}}=$ $=c_{0}^{\text {ann }} \exp \left[-E_{a}^{\mathrm{ann}} /\left(k_{\mathrm{B}} T\right)\right]$ are the constants of the $\mathrm{V}_{2} \mathrm{O}$ complex formation and annealing, respectively.

ISSN 2071-0194. Ukr. J. Phys. 2018. Vol. 63, No. 12 


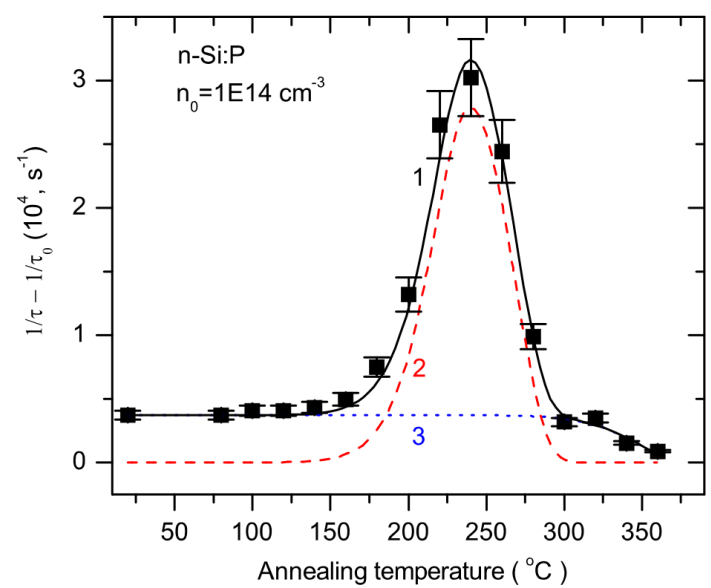

a

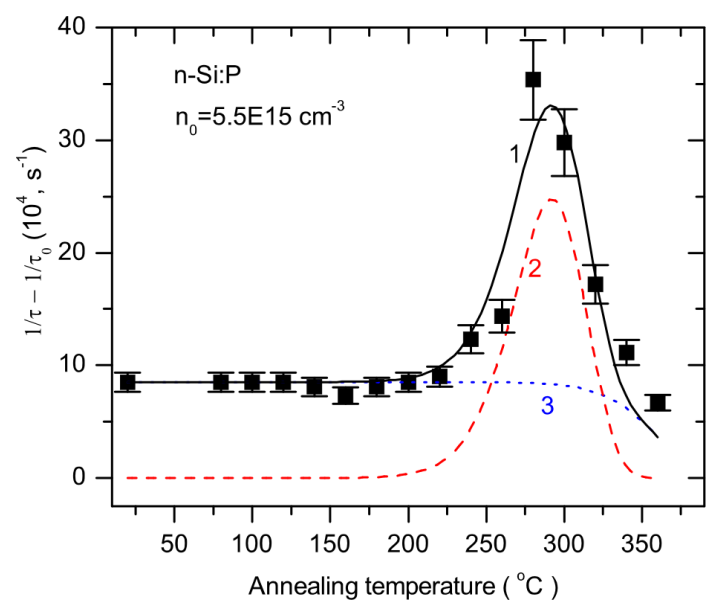

$c$

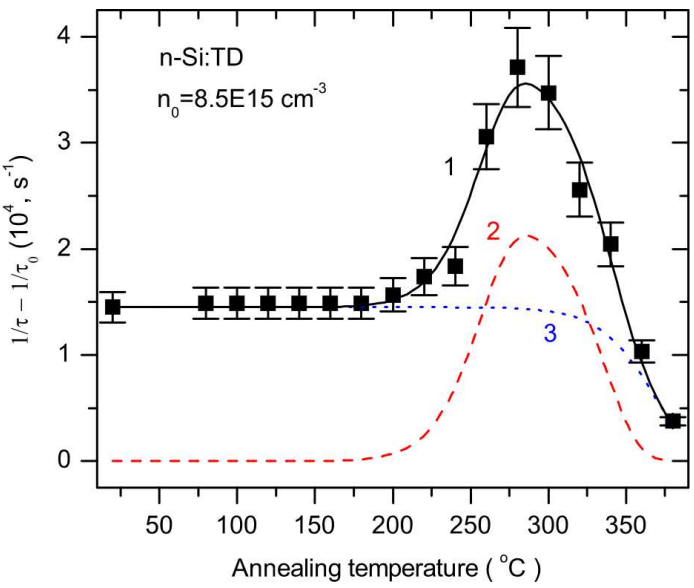

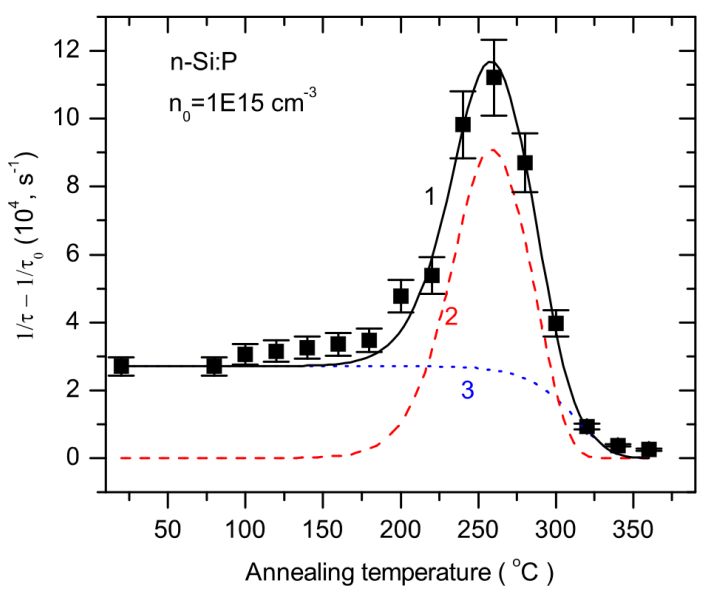

$b$

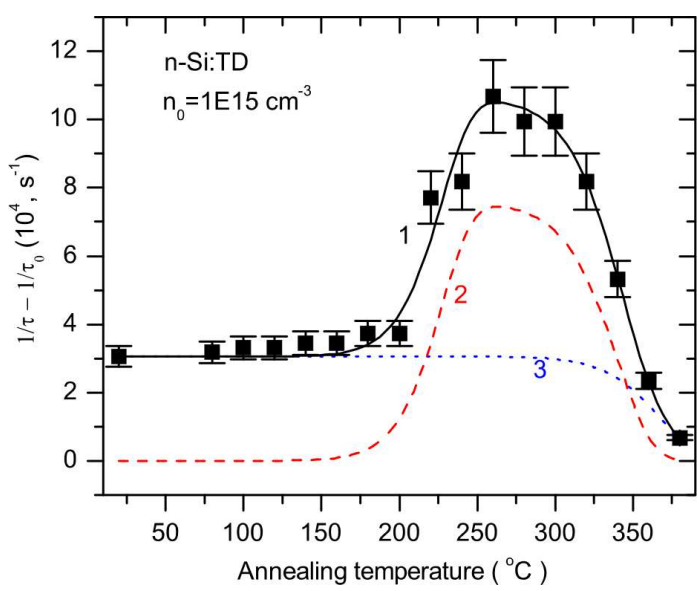

$d$

Fig. 7. Approximations (solid curves) of experimental dependences $\Delta \tau^{-1}\left(T_{\text {ann }}\right)$ for ${ }^{60} \mathrm{Co} \gamma$-irradiated $\mathrm{Cz}$ $n$-Si : $\mathrm{P}$ (panels $a, b$, and $c$ ) and $n$-Si : TD (panels $d$ and $e$ ) sources: total contribution (1), $\mathrm{V}_{2} \mathrm{O}(2)$, and VO (3) 
Table 2. Activation energies and frequency factors for the $\mathrm{V}_{2} \mathrm{O}$ formation and annealing and the $\mathrm{VO}$ annealing

\begin{tabular}{|c|c|c|c|c|c|c|c|}
\hline \multirow{2}{*}{ Specimen } & \multirow{2}{*}{$\begin{array}{c}n_{0}, \\
10^{15} \mathrm{~cm}^{3}\end{array}$} & \multicolumn{2}{|c|}{$\mathrm{V}_{2} \mathrm{O}$ formation } & \multicolumn{2}{|c|}{$\mathrm{V}_{2} \mathrm{O}$ annealing } & \multicolumn{2}{|c|}{ VO annealing } \\
\hline & & $c_{0}, \mathrm{~s}^{-1}$ & $E_{a}, \mathrm{eV}$ & $c_{0}, \mathrm{~s}^{-1}$ & $E_{a}, \mathrm{eV}$ & $c_{0}, \mathrm{~s}^{-1}$ & $E_{a}, \mathrm{eV}$ \\
\hline \multirow[t]{3}{*}{$n-\mathrm{Si}: \mathrm{P}$} & $\sim 0.1$ & $1.5 \times 10^{9}$ & 1.2 & $2.2 \times 10^{10}$ & 1.45 & $5.6 \times 10^{9}$ & 1.59 \\
\hline & $\sim 1$ & $1.5 \times 10^{9}$ & 1.24 & $3.3 \times 10^{10}$ & 1.52 & $5.6 \times 10^{9}$ & 1.54 \\
\hline & $\sim 5.5$ & $0.5 \times 10^{8}$ & 1.27 & $3.5 \times 10^{10}$ & 1.63 & $5.6 \times 10^{9}$ & 1.61 \\
\hline \multirow[t]{2}{*}{$n$-Si : TD } & $\sim 1$ & $1.5 \times 10^{9}$ & 1.23 & $7.5 \times 10^{9}$ & 1.56 & $5.6 \times 10^{9}$ & 1.64 \\
\hline & $\sim 8.5$ & $1.2 \times 10^{9}$ & 1.29 & $1.3 \times 10^{10}$ & 1.6 & $5.6 \times 10^{9}$ & 1.64 \\
\hline
\end{tabular}

Table 3. Cross-sections of hole capture on $\mathrm{V}_{2} \mathrm{O}$ and $\mathrm{VO}$ acceptor levels

\begin{tabular}{|c|c|c|}
\hline Defect & Level, eV & $\sigma_{p}$ at $293 \mathrm{~K}, \mathrm{~cm}^{2}$ \\
\hline $\mathrm{VO}(-/ 0)$ & $E_{c}-0.17$ & $(2.0 \pm 0.4) \times 10^{-13}$ \\
$\mathrm{~V}_{2} \mathrm{O}(2-/-)$ & $E_{c}-0.23$ & $(8 \pm 4) \times 10^{-12}$ \\
$\mathrm{~V}_{2} \mathrm{O}(-/ 0)$ & $E_{c}-0.47$ & $(5 \pm 2) \times 10^{-13}$ \\
\hline
\end{tabular}

The solution of Eqs. (6) with the initial conditions $\left[\mathrm{V}_{2}\right](t=0)=\left[\mathrm{V}_{2}\right]_{\text {irr }}$ and $\left[\mathrm{V}_{2} \mathrm{O}\right](t=0)=0$ is as follows:

$$
\begin{aligned}
& {\left[\mathrm{V}_{2} \mathrm{O}\right]=\frac{\left[\mathrm{V}_{2}\right]_{\text {irr }}}{\left(c_{\mathrm{V}_{2} \mathrm{O}}^{\mathrm{ann}} / c_{\mathrm{V}_{2} \mathrm{O}}-1\right)} \times} \\
& \times\left(\exp \left(-c_{\mathrm{V}_{2} \mathrm{O}} t\right)-\exp \left(-c_{\mathrm{V}_{2} \mathrm{O}}^{\operatorname{ann}} t\right)\right),
\end{aligned}
$$

where $t$ is the isochronous annealing time, $\left[\mathrm{V}_{2}\right]_{\text {irr }}$ the concentration of divacancies after the irradiation, and $\left[\mathrm{V}_{2} \mathrm{O}\right]$ the total concentration of $\mathrm{V}_{2} \mathrm{O}$ complexes, which is the sum of their concentrations in the singly and doubly charged negative states, because the Fermi level in our specimens is located above the $\mathrm{V}_{2} \mathrm{O}(-/ 0)$ level at room temperature.

Figure 7 demonstrates the experimental dependences $\Delta \tau^{-1}\left(T_{\text {ann }}\right)$ obtained for ${ }^{60} \mathrm{Co} \gamma$-irradiated $\mathrm{Cz}$ $n$-Si : P (panels $a, b$, and $c$ ) and $n$-Si:TD (panels $d$ and $e$ ) specimens together with their description, by using expressions (5) and (2) with the fitting parameters of $\mathrm{VO}$ and $\mathrm{V}_{2} \mathrm{O}$ defects quoted in Tables 2 and 3 . The concentration of $\mathrm{V}_{2} \mathrm{O}$ complexes was calculated with the help of expression (7). The required $\left[\mathrm{V}_{2}\right]_{\text {irr }}$ value was calculated taking into account that the ratio $\eta_{\mathrm{VO}} / \eta_{\mathrm{V}_{2}} \approx 10^{2}$ for ${ }^{60} \mathrm{Co} \gamma$-irradiated $\mathrm{Cz} n$-Si $[1,23]$. At $T_{\text {ann }}>300^{\circ} \mathrm{C}$, the $\mathrm{VO}$ and $\mathrm{V}_{2} \mathrm{O}$ complexes are annealed simultaneously. Therefore, in order to correctly determine the $\mathrm{V}_{2} \mathrm{O}$ parameters, we separated the influence of $\mathrm{VO}$ on $\tau$. For this purpose, the annealing constant $c_{\mathrm{VO}}=5.6 \times 10^{9} \exp \left[-1.7 /\left(k_{\mathrm{B}} T\right)\right]$ was taken from work [1] as the basic one, and only the $E_{a}$-value for the VO annealing was corrected according to our experimental data (see Table 2).

From Table 2 , one can see that the average $E_{a^{-}}$ value for the $\mathrm{V}_{2} \mathrm{O}$ formation equals $1.25 \pm 0.05 \mathrm{eV}$ for both $\mathrm{Cz} n$-Si groups. This result is in good agreement with the data demonstrating that the processes of $\mathrm{V}_{2}$ annealing $[12,25]$ and $\mathrm{V}_{2} \mathrm{O}$ formation [12] are characterized by the same value $E_{a} \approx 1.3 \mathrm{eV}$. The annealing of $\mathrm{V}_{2} \mathrm{O}$ is characterized by the value $E_{a}^{\mathrm{ann}}=$ $=1.54 \pm 0.09 \mathrm{eV}$ (see Table 2) as in theoretical work [26], but it is lower than a value of about $2 \mathrm{eV}$ obtained in experimental work [27]. We also obtained $E_{a}$ and $c_{0}$ values similar to ours, when using the experimental dependences for the concentration changes of $\mathrm{V}_{2}$ and $\mathrm{V}_{2} \mathrm{O}$ complexes at the isochronous annealing of electron-irradiated $\mathrm{Cz} n$-Si (see Fig. 5 in work [11]). Note also that there is a tendency for the activation energies of $\mathrm{V}_{2} \mathrm{O}$ formation and annealing to grow with $n_{0}$ (Table 2), which correlates with the shift of the $k_{\tau}^{\text {peak }}$ peak toward higher annealing temperatures (Fig. 3). It is evident that the $\mathrm{V}_{2} \mathrm{O}$ charge state can play a key role in this situation. This issue is not considered in this paper.

The dependence $\Delta k_{\tau}^{\text {peak }}\left(n_{0}\right)$ (curve 1 in Fig. 4) corresponds to the maximum contribution of $\mathrm{V}_{2} \mathrm{O}$ to the total change of $k_{\tau}$, when all $\mathrm{V}_{2}$ are transformed into $\mathrm{V}_{2} \mathrm{O}$. In this case, the calculations show that $\tau$ is driven by the $\mathrm{V}_{2} \mathrm{O}(-/ 0)$ level in high-resistive $n$-Si $\left(n_{0}<5 \times 10^{14} \mathrm{~cm}^{-3}\right.$, curve 3 in Fig. 4) and the $\mathrm{V}_{2} \mathrm{O}$ $(2-/-)$ level in low-resistive $n$-Si $\left(n_{0}>5 \times 10^{14} \mathrm{~cm}^{-3}\right.$, curve 2 in Fig. 4). The dependence $\Delta k_{\tau}^{\text {peak }}\left(n_{0}\right)$ grows

ISSN 2071-0194. Ukr. J. Phys. 2018. Vol. 63, No. 12 
due to the increase in the electron occupation of the $\mathrm{V}_{2} \mathrm{O}(2-/-)$ level, for which $\sigma_{p}$ is larger than for the $\mathrm{V}_{2} \mathrm{O}(-/ 0)$ one (see Table 3$)$. At the same time, the total contribution of $\mathrm{V}_{2} \mathrm{O}$ (curve 1 in Fig. 4) to the degradation of $\tau$ in the examined $n_{0}$-interval is much larger than that of VO (the main recombination center in ${ }^{60} \mathrm{Co} \gamma$-irradiated $\mathrm{Cz} n$-Si, Fig. 2), despite that the formation efficiency of primary $\mathrm{V}_{2}$ (and, accordingly, the $\mathrm{V}_{2} \mathrm{O}$ concentration maximum) is approximately two orders of magnitude smaller than the formation efficiency of VO. However, the large value of $\eta_{\mathrm{VO}}$ is compensated (i) in high-resistive $n$-Si by a low filling degree of the VO acceptor level by electrons (about $10^{-3}$ at $n_{0}=1 \times 10^{14} \mathrm{~cm}^{-3}$ ), whereas $\sigma_{p, \mathrm{VO}} \sim \sigma_{p, \mathrm{~V}_{2} \mathrm{O}(-/ 0)}$, and (b) in low-resistive $n$-Si by the fact that $\sigma_{p, \mathrm{~V}_{2} \mathrm{O}(2-/-)}>\sigma_{p, \mathrm{VO}}$.

\section{Conclusion}

To summarize, it is found that the lifetime of nonequilibrium charge carriers in $\mathrm{Cz} n$-Si irradiated either with ${ }^{60} \mathrm{Co} \gamma$-quanta or $1-\mathrm{MeV}$ electrons significantly decreases after the isochronous annealing within a temperature interval of about $180-280^{\circ} \mathrm{C}$, with the efficiency of this process depending on $n_{0}$. Using specimens with various impurity compositions, but having the conductivity of the $n$-type, we have shown that the modification of recombination properties in $\mathrm{Cz} n$ $\mathrm{Si}$ specimens firstly irradiated and then annealed in a temperature interval of $180-380^{\circ} \mathrm{C}$ is governed by the formation and annealing of $\mathrm{V}_{2} \mathrm{O}$ complexes. By analyzing the experimental data with the use of the Shockley-Reed-Hall statistics, it is found that the formation and annealing of $\mathrm{V}_{2} \mathrm{O}$ complexes are characterized by an activation energies of $1.25 \pm 0.05 \mathrm{eV}$ and $1.54 \pm 0.09 \mathrm{eV}$, respectively. We also determined the values of $\sigma_{p}$ for singly and doubly charged $\mathrm{V}_{2} \mathrm{O}$ acceptor states: $(5 \pm 2) \times 10^{-13}$ and $(8 \pm 4) \times 10^{-12} \mathrm{~cm}^{2}$, respectively. We have also analyzed and compared the influence of $\mathrm{V}_{2} \mathrm{O}$ and $\mathrm{VO}$ defects on $k_{\tau}$ in $\mathrm{Cz}$ $n$-Si specimens with the free electron concentrations within the interval $n_{0} \sim 10^{14} \div 10^{16} \mathrm{~cm}^{-360}$, which were subsequently subjected to the ${ }^{60} \mathrm{Co} \gamma$-irradiation and annealing.

1. S.D. Brotherton, P. Bradley. Defect production and lifetime control in electron and $\gamma$-irradiated silicon. J. Appl. Phys. 53, 5720 (1982)

2. A. Hallen, N. Keskitalo, F. Masszi, V. Nagl. Lifetime in proton irradiated silicon. J. Appl. Phys. 79, 3906 (1996).
3. H. Bleichner, P. Jonsson, N. Keskitalo, E. Nordlander. Temperature and injection dependence of the ShockleyRead-Hall lifetime in electron-irradiated $p$-type silicon, J. Appl. Phys. 79, 9142 (1996).

4. M. Kras'ko, A. Kraitchinskii, A. Kolosiuk, V. Voitovych, R. Rudenko, V. Povarchuk. Radiation damage of carrier lifetime and conductivity in $\mathrm{Sn}$ and $\mathrm{Pb}$ doped $n$-Si. Solid State Phenom. 205-206, 323 (2014).

5. E. Gaubas, E. Simoen, J. Vanhellemont. Carrier lifetime spectroscopy for defect characterization in semiconductor materials and devices. ECS J. Solid State Sci. 5, 3108 (2016).

6. Y.-H. Lee, J.W. Corbett. EPR studies of defects in electron-irradiated silicon: A triplet state of vacancy-oxygen complexes, Phys. Rev. B 13, 2653 (1976).

7. M. Moll, H. Feick, E. Fretwurst, G. Lindstrom, C. Schutze. Comparison of defects produced by fast neutrons and ${ }^{60} \mathrm{Co}-$ gammas in high-resistivity silicon detectors using deeplevel transient spectroscopy, Nucl. Instrum. Meth. Phys. A 388, 335 (1997).

8. K. Gill, G. Hall, B. MacEvoy. Bulk damage effects in irradiated silicon detectors due to clustered divacancies. J. Appl. Phys. 82, 126 (1997).

9. E. Monakhov, B. Avset, A. Hallen, B. Svensson. Formation of a double acceptor center during divacancy annealing in low-doped high-purity oxygenated Si. Phys. Rev. B 65, 233207 (2002).

10. G. Alfieri, E. Monakhov, B. Avset, B. Svensson. Evidence for identification of the divacancy-oxygen center in $\mathrm{Si}$. Phys. Rev. B 68, 233202 (2003).

11. V. Markevich, A. Peaker, S. Lastovskii, L. Murin, J. Lindstrom. Defect reactions associated with divacancy elimination in silicon. J. Phys.: Condens. Matter 15, S2779 (2003).

12. M. Mikelsen, E. Monakhov, G. Alfieri, B. Avset, B. Svensson. Kinetics of divacancy annealing and divacancy-oxygen formation in oxygen-enriched high-purity silicon. Phys. Rev. B 72, 195207 (2005).

13. M.-A. Trauwaert, J. Vanhellemont, H. Maes, A.-M. Van Bavel, G. Langouche, P. Clauws. Low-temperature anneal of the divacancy in $p$-type silicon: A transformation from $\mathrm{V}_{2}$ to $\mathrm{V}_{x} \mathrm{O}_{y}$ complexes? Appl. Phys. Lett. 66, 3056 (1995).

14. V. Markevich, A. Peaker, B. Hamilton, S. Lastovskii, L. Murin, J. Coutinho, V.J.B. Torres, L. Dobaczewski, B.G. Svensson. Structure and electronic properties of trivacancy and trivacancy-oxygen complexes in silicon. Phys. Status Solidi A 208, 568 (2011).

15. N. Ganagona, B. Raeissi, L. Vines, E. Monakhov, B. Svensson. Formation of donor and acceptor states of the divacancy-oxygen centre in p-type Cz-silicon. J. Phys.: Condens. Matter 24, 435801 (2012).

16. V. Markevich, A. Peaker, B. Hamilton, S. Lastovskii, L. Murin. Donor levels of the divacancy-oxygen defect in silicon. J. Appl. Phys. 115, 012004 (2014). 
17. I. Pintilie, E. Fretwurst, G. Lindstrom, J. Stahl. Close to midgap trapping level in ${ }^{60} \mathrm{Co}$ gamma irradiated silicon detectors. Appl. Phys. Lett. 81, 165 (2002).

18. M. Kras'ko, A. Kraitchinskii, V. Neimash, A. Kolosiuk, L. Shpinar. On the nature of "negative" annealing of the nonequilibrium charge carrier lifetime in irradiated $n$-Si, Ukr. J. Phys. 52, 162 (2007).

19. V. Markevich, A. Peaker, S. Lastovskii, V. Gusakov, I. Medvedeva, L. Murin. Formation of radiation-induced defects in Si crystals irradiated with electrons at elevated temperatures. Solid State Phenom. 156-158, 299 (2010).

20. V. Neimash, V. Siratskii, M. Sosnin, V. Shakhovtsov, V. Shindich. The thermal donors influence on radiation defecting in silicon, Fiz. Tekh. Poluprovodn. 23, 250 (1989) (in Russian).

21. I. Kolkovskii, P. Lugakov, V. Shusha. Charge-carrier recombination in silicon irradiated with $\gamma$-rays of different energies. Phys. Status Solidi A 83, 299 (1984).

22. M. Kras'ko, V. Neimash, A. Kraitchinskii, A. Kolosiuk, O. Kabaldin. Influence of A- and E-centers on the lifetime of nonequilibrium charge carriers in $\gamma$-irradiated $n$-Si. $U k r$. J. Phys. 53, 683 (2008).

23. A. Zubrilov, S. Koveshnikov, Effect of impurity composition of $\mathrm{n}$-type $\mathrm{Si}$ on the radiation-induced defect formation and degradation of minority-charge-carrier lifetime under $\gamma$-irradiation. Fiz. Tekh. Poluprovodn. 25, 1332 (1991) (in Russian).

24. M.-L. David, E. Simoen, C. Claeys, V. Neimash, M. Kras'ko, A. Kraitchinskii, V. Voytovych, A. Kabaldin, J.F. Barbot. On the effect of lead on irradiation induced defects in silicon. Solid State Phenom. 108-109, 373 (2005).

25. P. Pellegrino, P. Lévêque, J. Lalita, A. Hallé, B.G. Svensson. Annealing kinetics of vacancy-related defects in lowdose $\mathrm{MeV}$ self-ion-implanted $n$-type silicon, Phys. Rev. B 64, 195211 (2001).

26. J. Coutinho, R. Jones, S. Öberg, P. Briddon. The formation, dissociation and electrical activity of divacancyoxygen complexes in Si. Physica B 340-342, 523 (2003).
27. M. Mikelsen, J. Bleka, J. Christensen, E. Monakhov, B. Svensson. Annealing of the divacancy-oxyge and vacancy-oxygen complexes in silicon. Phys. Rev. B 75, 155202 (2007).

Received 05.07.18.

Translated from Ukrainian by O.I. Voitenko

М.М. Красъко, А.Г. Колосюк,

В.В. Войтович, В.Ю. Поварчук, І.С. Рогуцъкий

ВПЛИВ ДЕФЕКТІВ

ДИВАКАНСІЯ-КИСЕНЬ НА РЕКОМБІНАЦЙНІ

ВЛАСТИВОСТІ $n$-Si ПІСЛЯ ОПРОМІНЕННЯ

ТА НАСТУПНОГО ВІДПАЛУ

$\mathrm{P}$ е $з$ ю м е

Детально досліджено зміну рекомбінаційних властивостей опроміненого $\gamma$-квантами ${ }^{60} \mathrm{Co}$ чи $1 \mathrm{MeB}$ електронами кремнію $n$-типу провідності з концентрацією вільних електронів $n_{0} \sim 10^{14}-10^{16} \mathrm{~cm}^{-3}$, вирощеного методом Чохральського ( $\mathrm{Cz} n-\mathrm{Si})$, після ізохронного відпалу в температурному діапазоні $180-380{ }^{\circ} \mathrm{C}$, в якому відбувається утворення та відпал комплексів дивакансія-кисень $\left(\mathrm{V}_{2} \mathrm{O}\right)$. Виявлено, що час життя нерівноважних носіїв заряду $(\tau)$ суттєво зменшується після відпалу в діапазоні $\sim 180-280{ }^{\circ} \mathrm{C}$ і цей ефект є сильнішим у низькоомному $n$-Si. Показано, що зміна $\tau$ після відпалу в діапазоні $180-380{ }^{\circ} \mathrm{C}$ зумовлена дефектом дивакансійної природи, найімовірніше $\mathrm{V}_{2} \mathrm{O}$. Було визначено, аналізуючи експериментальні дані за допомогою статистики Шоклі-Ріда-Холла, що утворення $\mathrm{V}_{2} \mathrm{O}$ характеризується енергією активації $E_{a}=1,25 \pm 0,05 \mathrm{eB}$ i частотним фактором $\mathrm{c}_{0}=(1 \pm 0,5) \cdot 10^{9} \mathrm{c}^{-1}$, а їх відпал енергією активації $E_{a}^{a n n}=1,54 \pm 0,09 \mathrm{eB}$ і частотним фактором $c_{0}^{\text {ann }}=(2,1 \pm 1,4) \cdot 10^{10} \mathrm{c}^{-1}$. Також отримано значення поперечного перерізу захоплення дірок $\left(\sigma_{p}\right)$ одно- $\mathrm{i}$ двозарядними акцепторними станами $\mathrm{V}_{2} \mathrm{O}:(5 \pm 2) \cdot 10^{-13} \mathrm{i}$ $(8 \pm 4) \cdot 10^{-12} \mathrm{~cm}^{2}$ відповідно. 